\title{
Selection of arabica coffee progenies tolerant to heat stress
}

\author{
Seleção de progênies de café arábica tolerantes ao calor
}

\author{
Alexsandro Lara Teixeira ${ }^{\mathrm{I}^{*}}$ Flávio de França Souza ${ }^{\mathrm{II}}$ Antonio Alves Pereira ${ }^{\mathrm{III}}$ \\ Antonio Carlos Baião de Oliveira ${ }^{\mathrm{IV}}$ Rodrigo Barros Rocha ${ }^{\mathrm{I}}$
}

\begin{abstract}
Due to high temperatures, practically all coffee farms in the state of Rondonia are of the $\boldsymbol{C}$. canephora species. Thus, importing arabica coffee from other states becomes necessary for composition of blends, as well as for the specialty or gourmet coffee market. The purpose of this study was to select arabica coffee genotypes that exhibit satisfactory agronomic performance under high temperature conditions. The experiment was conducted in Ouro Preto do Oeste, $R O$, Brazil, with mean annual temperature of $25.8^{\circ} \mathrm{C}$ and mean annual rainfall of $2300 \mathrm{~mm}$ year ${ }^{1}$. The experiment was composed of 114 arabica coffee genotypes, with 103 progenies and eleven control cultivars, provided by EPAMIG. A randomized block experimental design was used with three replications, spacing of 3.0x1.0 meters and five plants per plot. All the crop seasons showed significant difference for the green coffee yield trait. In joint analysis, significant differences were detected among progenies and control cultivars. In the average of the four harvests, green coffee yield was 32.38 bags $h a^{-1}$. The cultivars 'Catuai Vermelho IAC 15', 'Obatã IAC 1669-20' and 'Catucai Amarelo 2SLCAK' stood out, achieving yields greater than 40 bags ha-1. The gain obtained from selection was 14.33 bags $h a^{-1}$, which is equivalent to an increase of $44.04 \%$ in production of green coffee. The progeny H514-7-10-6-2-3-9 stood out with an average yield of $51.20 \mathrm{bags} \mathrm{ha}^{-1}$. In regard to maturation cycle, $56 \%$ of the progenies were classified as early maturity and $44 \%$ as medium maturity. Late maturity genotypes were not observed.
\end{abstract}

Key words: Coffea Arabica L., high temperatures, heat tolerance, maturation cycle.

\section{RESUMO}

Devido às temperaturas elevadas, basicamente, todas as lavouras de café no estado de Rondônia são da espécie $\boldsymbol{C}$. canephora. Desse modo, a importação de café arábica de outros estados faz-se necessária para a composição dos blends, além do mercado de cafés especiais ou gourmets. O objetivo deste trabalho foi selecionar genótipos de café arábica que apresentam desempenho agronômico satisfatório sob condições de temperaturas elevadas. $O$ experimento foi instalado em Ouro Preto do Oeste-RO, com temperaturas médias anuais de $25,8^{\circ} \mathrm{C}$ e precipitação pluvial média de $2.300 \mathrm{~mm}$ ano $^{-1}$. O experimento foi composto por 114 genótipos de café arábica, sendo 103 progênies e onze cultivares testemunhas, fornecidas pela EPAMIG. O delineamento foi blocos casualizados com três repetições, espaçamento de 3,0 x 1,0 metros, com cinco plantas por parcela. Todas as safras demonstraram diferença significativa para a característica produtividade de café beneficiado. Na análise conjunta, foram detectadas diferenças significativas entre progênies e entre cultivares testemunhas. Na média das quatro colheitas, a produtividade de café beneficiado foi de 32,38 sacas $h a^{-1}$. Destaques para as cultivares 'Catuai Vermelho IAC 15', 'Obatã IAC 1669-20'e 'Catucaí Amarelo $2 S L C A K$ ' que alcançaram produtividades acima de 40 sacas $h a^{-1}$. O ganho de seleção obtido foi de 14,33 sacas $h^{-1}$, que equivale a um aumento de 44,04\% na produção de café beneficiado. Destaque para a progênie H514-7-10-6-2-3-9, com produtividade média de 51,20 sacas $h a^{-1}$. Quanto ao ciclo de maturação, 56\% das progênies foram classificadas como ciclo precoce e $44 \%$ de ciclo intermediário. Não foi observado genótipo de ciclo tardio.

Palavras-chave: Coffea arabica L., temperaturas elevadas, tolerância ao calor, ciclo de maturação.

\section{INTRODUCTION}

In 2012, Brazil achieved record production of 50.8 million bags of coffee, consolidating its position as the largest producer and exporter in the world market. Of the total produced, the Coffea arabica species represents $76 \%$ of the beans, while

IEmbrapa Rondônia, Centro de Pesquisa Agroflorestal de Rondônia, 76815-800, Porto Velho, RO, Brasil. E-mail: alexsandro.teixeira@embrapa.br. ${ }^{*}$ Corresponding author.

IIEmbrapa Semiárido, Centro Nacional de Pesquisa do Semiárido, Petrolina, PE, Brasil.

IIIEmpresa de Pesquisa Agropecuária de Minas Gerais, Viçosa, MG, Brasil.

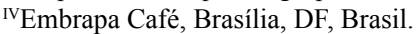


the Coffea canephora species represents 24\%. In the same year, the state of Rondonia was the sixth largest coffee producer in the country with production of 1.42 million bags, which is wholly composed of beans from the $\boldsymbol{C}$. canephora species (ABIC, 2012).

Coffee farming in Rondonia began in the 1970s when the state was still known as the "Federal Territory of Rondonia", colonized by immigrants coming from the South and Southeast regions of Brazil. Through the tradition of growing arabica coffee, the first coffee crops introduced in the state were the cultivars 'Mundo Novo' and 'Catuaí'(SOUZA \& SANTOS, 2009).

Due to the occurrence of high temperatures throughout the year, especially from June to August, the crops had yields far below expectations. As a result of this, there were changes toward a preference for planting the Coffea canephora species, 'Conilon' and 'Robusta' subgroups, which show greater hardiness and moderate drought tolerance. This situation created a deficit in the local market causing the state to no longer be an exporter of arabicatype beans in the 1970s and 1980s, becoming an importer of the product (SOUZA \& SANTOS, 2009).

The monthly consumption of the state is 714,000 bags and the local industries have a 45 to $50 \%$ share of this total. In practice, nearly all the coffee produced, processed and consumed in Rondonia are canephora beans. Thus, importing arabica coffee from other states becomes necessary for composition of blends, as well as for the specialty or gourmet coffee market, which may represent $5 \%$ of the regional market.

The main problem observed in the arabica coffee crops under high temperatures is the lack of uniformity in maturation and high rates of early maturity in the fruits. Arabica coffee expresses its full potential with mean annual temperatures ranging from 18 to $23^{\circ} \mathrm{C}$. Above $23^{\circ} \mathrm{C}$, accelerated growth and development of the fruits result in loss of quality (CAMARGO, 1985). Furthermore, according to DAMATTA \& RAMALHO (2006), continual exposure to temperatures above $30^{\circ} \mathrm{C}$ may result in reduction in growth rate and the appearance of anomalies, such as yellowing of leaves. High air temperature during flowering, associated with a prolonged dry season, may result in abortion of flowers (FAZUOLI et al., 2007; BERGO et al., 2008).

Tolerance to heat stress in plants is defined as the ability of the plant to grow and produce economic return under high temperatures. In tropical climates, the excess of radiation and high temperatures are often the most limiting factors, which affect crop growth and production. For selection of plants tolerant to heat stress, yield is the main trait used in most cases (WAHID et al., 2007; SOUZA et al., 2011).

It is estimated that coffee production may decrease by more than $80 \%$ in years with accentuated water deficit in some regions at the margin of those regions which are optimal for greatest yield (DAMATTA \& RAMALHO, 2006). Considering climate change and global warming reported in recent years (CAMARGO, 2010), evaluations under stress conditions may also be able to contribute to selection of genotypes that may be introduced in other regions of the country, making coffee growing viable in regions that will probably be unsuitable in the near future.

In light of the above, the purpose of this study was to select arabica coffee genotypes that show satisfactory agronomic performance under high temperature conditions with a view toward growing them in the state of Rondonia and in other regions that are marginal for arabica coffee growing.

\section{MATERIALS AND METHODS}

The experiment was set up in September 2005 in the Embrapa experimental field, municipality of Ouro Preto do Oeste, RO, which is situated at the coordinates $10^{\circ} 44$ '53'S and $62^{\circ} 12^{\prime} 57^{\prime}$ 'W. The climate of the region is classified as Tropical Wet and Dry, Aw (Köppen), with mean annual temperatures of $25.8^{\circ} \mathrm{C}$ and mean annual rainfall of $2300 \mathrm{~mm}$. The mean altitude of the region is 240 meters, with relative air humidity near $82 \%$ most of the year.

The experiment was composed of 114 genotypes of arabica coffee, with 103 progenies (advanced generations) and eleven control cultivars (recommended for the Southeast region of Brazil), provided by the Empresa de Pesquisa Agropecuária de Minas Gerais (EPAMIG) (Crop and Livestock Research Company of Minas Gerais). A randomized block experimental design was used with three replications, spacing of 3.0 x 1.0 meters, with five plants per plot. The experiments were evaluated during four crop season (2007/2008, 2008/2009, 2009/2010 and 2011/2012) and conducted according to the fertilization recommendations for the coffee crop. The normal management practices used for the crop were adopted. Problems in the release of funds in 2010 damaged the cultivation and harvesting of the 2010/2011 season, making it impossible to collect data.

The following traits were evaluated: Yield - in $60 \mathrm{~kg}$ bags of green coffee per hectare (bags ha ${ }^{-1}$ ) harvest was performed in individual plots and production evaluated in liters of "field coffee" ("café da roça" - coffee at all stages of maturity) per plot. After that, conversion of 
the volume of coffee collected to bags ha $^{-1}$ was performed by approximation of values, considering average yield of $480 \mathrm{~L}$ of "field coffee" for each $60 \mathrm{~kg}$ bag of green coffee, which corresponds to the average yield adopted in all regions. Maturation cycle- defined by the time interval between flowering and harvest. The interval of 20 to 30 days between harvests was used as a criterion to classify the genotypes as early (E), medium (M) or late (L). Percentage of empty locule fruits - selection of fifty fruits in the cherry stage was made from a one-liter sample of coffee. Then the selected fruits were deposited in a container with water. The number of floaters was counted and this result was multiplied by two, obtaining the percentage of empty locule fruits (MEDINA FILHO \& BORDIGNON, 2003).

The data obtained in reference to green coffee yield were subjected to analysis of variance with the significance of the effects verified by the $\mathrm{F}$ test at $5 \%$ probability. Selective accuracy $\left(\hat{r}_{\hat{g} g}\right)$, determined by means of the expression: $\hat{r}_{g g}=(1-1 / \mathrm{F})^{1 / 2}$, in which F is the value of the Snedecor F test for the genotype effect (RESENDE \& DUARTE, 2007), and was estimated so as to gauge experimental precision. Analyses of variance, repeatability and gain from selection were perfomed using the computational software GENES (CRUZ, 2006). The statistical analyzes were processed considering fixed model for all genotypes and crop seasons.

\section{RESULTS AND DISCUSSSION}

All the crop seasons showed significant difference for the green coffee yield trait (Table 1). The estimates of selective accuracy may be considered to be of high magnitude in all the crop seasons $(77.33<$ $\left.\hat{r}_{\hat{g} g}<93.92\right)$, indicating good experimental precision. The use of accuracy as a measure of experimental precision, suggested by RESENDE \& DUARTE (2007), has the advantage of not depending on the mean, which provides greater security in the use of phenotypic expression as an indicator of genotypic variation. Accuracy values above $70 \%$ indicate high experimental precision.

The lowest mean yield of green coffee was observed in the 2007/08 crop season ( 9.62 bags ha $^{-1}$ ). The reason for low yield is due to the fact that this was the first crop. In the first harvest, a greater variation is usually observed in the genotypic values for this trait. In subsequent harvests, these differences tend to diminish, which reinforces the fact that there is a need for evaluations in more than one crop season, providing reliability to the selection process and to the estimates of genetic values. In 2008/09 crop season, the overall mean of green coffee was of 30.20 bags ha $^{-1}$. The 2009/2010 and 2011/2012 crop seasons obtained satisfactory production, with mean yields of 47.36 and 43.01 bags

Table 1 - Summary of joint analysis of variance and estimates of heritability $\left(h^{2}\right)$ and selective accuracy $\left(\hat{r}_{\hat{g} g}\right)$ for green coffee yield (bags $\mathrm{ha}^{-1}$ ), in reference to the $2007 / 2008,2008 / 2009,2009 / 2010$ and 2011/2012 crop seasons.

\begin{tabular}{|c|c|c|c|}
\hline \multirow{2}{*}{ FV } & \multirow{2}{*}{ GL } & \multicolumn{2}{|c|}{ 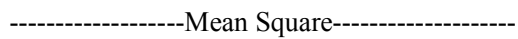 } \\
\hline & & -----------Green co & $($ bags ha-1)--------- \\
\hline Blocks & 2 & 567.6599 & \\
\hline Treatments & 113 & 1055.2493 & ** \\
\hline Progenies & 102 & 1108.9056 & ** \\
\hline Controls & 10 & 578.6617 & ** \\
\hline Among groups & 1 & 348.1832 & ${ }^{*}$ \\
\hline Crop seasons & 3 & 98014.6178 & ** \\
\hline Treatments $\mathrm{x}$ crop seasons & 339 & 147.5624 & ** \\
\hline Progenies $\mathrm{x}$ crop seasons & 306 & 147.1753 & ** \\
\hline Controls x crop seasons & 30 & 132.5453 & ** \\
\hline Groups $\mathrm{x}$ crop seasons & 3 & 337.2237 & ** \\
\hline Residue & 910 & 75.0464 & \\
\hline Mean of progenies & 32.38 & & \\
\hline Mean of controls & 34.09 & & \\
\hline Overall Mean & 32.55 & & \\
\hline Heritability $\left(h^{2}\right)$ & 93.23 & & \\
\hline Selective Accuracy $\hat{r}_{\hat{g} g}$ & 92.75 & & \\
\hline
\end{tabular}

\footnotetext{
${ }^{* *},{ }^{*}$ : Significant at $1 \%$ and $5 \%$ by the $\mathrm{F}$ test, respectively.
} 
$\mathrm{ha}^{-1}$, respectively. These values become expressive when considering that the trials were conducted under high temperature conditions (Figure 1).

In joint analysis, significant differences were detected among progenies and among control cultivars, showing that there is genetic variability among the genotypes evaluated. The progenies vs. control contrast was also significant, indicating that they presented different behaviors (Table 1).

The mean value of the four harvests for green coffee yield was of 32.38 bags ha $^{-1}$. The control cultivar also obtained satisfactory performance, with a mean value of 34.09 bags ha-1 $^{-1}$ The cultivars 'Catuaí Vermelho IAC 15', 'Obatã IAC 1669-20' and 'Catucaí Amarelo 2SLCAK' stood out, which achieved yields above 40 bags ha $^{-1}$. This indicates the importance of including them in the Value for Cultivation and Use trials, for the purpose of extending recommendations for planting these cultivars in the state.

According to BORÉM (2005), for a good selection process, the genetic material used as a control should be represented by cultivars recommended for the region where the selection process is performed. Nevertheless, if these materials do not exist, cultivars recommended in other regions are used, or even genetic materials from the breeding program itself that show good performance in the edaphoclimatic conditions of the region.

Among the progenies evaluated, 13\% were greater than the best control, with yields above 44 bags ha ${ }^{-1}$. By means of decomposition of the sum of squares of the progeny $\mathrm{x}$ crop season interaction, significance was observed for green coffee yield, showing that the progeny behavior did not coincide in all the crop seasons. The group $\mathrm{x}$ crop season contrast was significant, indicating that the performance of the progenies was different than of the controls.

For the percentage of the empty locule fruit characteristic, the mean value of the progenies was $15 \%$ (Table 2). This value is similar to that found in the commercial crop areas of the Southeast of Brazil, indicating that this characteristic was not negatively affected by the effect of high temperatures. There was not incidence of orange rust throughout the crop cycle making it impossible to evaluate the genotypes in regard to resistance to the pathogen.

The estimate of heritability observed for green coffee yield was $93.23 \%$. According to MOHSIN et al. (2009), values of this magnitude ensure success in

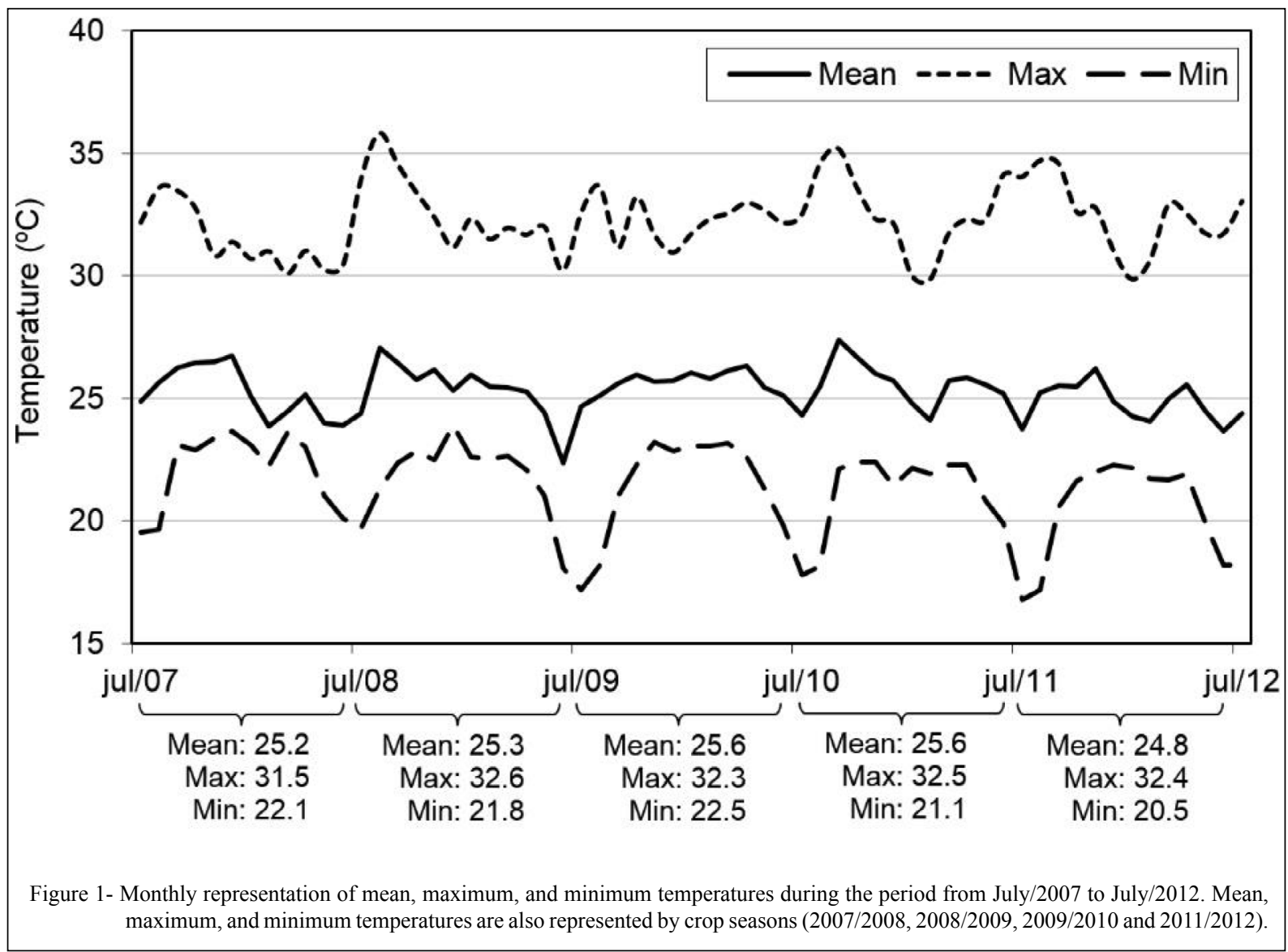

Ciência Rural, v.45, n.7, jul, 2015. 
Table 2 - Listing of the thirty best classified progenies and eleven control cultivars of Coffea arabica for green coffee yield (bags ha ${ }^{-1}$ ), percentage of empty locule fruits (\%), maturation cycle and color of the fruits, in reference to the 2007/2008, 2008/2009, $2009 / 2010$ and $2011 / 2012$ crop seasons.

\begin{tabular}{|c|c|c|c|c|}
\hline Genotype & Green coffee yield (bags ha ${ }^{-1}$ ) & Empty Locule Fruits (\%) & Maturation $\mathrm{Cycle}^{1}$ & Fruit Color ${ }^{2}$ \\
\hline H514-7-10-6-2-3-9 & 51.20 & 9 & $\mathrm{E}$ & $\mathrm{R}$ \\
\hline H514-7-10-6-25 & 50.40 & 12 & $\mathrm{E}$ & $\mathrm{R}$ \\
\hline H493-1-2-8 & 49.92 & 6 & M & $\mathrm{R}$ \\
\hline H514-7-10-6-29 & 48.65 & 14 & M & $\mathrm{R}$ \\
\hline H419-10-6-2-1-8 & 48.25 & 23 & M & $\mathrm{R}$ \\
\hline H514-7-10-6-9 & 48.25 & 17 & M & $\mathrm{R}$ \\
\hline H419-10-6-2-1-10 & 46.71 & 19 & $\mathrm{E}$ & $\mathrm{Y}$ \\
\hline H514-7-10-6-15 & 45.77 & 14 & $\mathrm{E}$ & $\mathrm{R}$ \\
\hline H514-7-10-6-23 & 45.33 & 10 & M & $\mathrm{R}$ \\
\hline H419-10-6-2-3-19 & 44.72 & 18 & $\mathrm{E}$ & $\mathrm{Y}$ \\
\hline H419-10-6-2-3-18 & 44.63 & 10 & $\mathrm{E}$ & $\mathrm{Y}$ \\
\hline H514-7-10-6-12 & 44.47 & 13 & M & $\mathrm{R}$ \\
\hline H514-7-10-6-10 & 44.28 & 11 & M & $\mathrm{R}$ \\
\hline H514-7-10-6-17 & 44.27 & 15 & M & $\mathrm{R}$ \\
\hline H514-7-10-6-22 & 43.98 & 14 & M & $\mathrm{R}$ \\
\hline H514-7-10-6-16 & 43.72 & 11 & $\mathrm{E}$ & $\mathrm{R}$ \\
\hline H419-10-6-2-3-5 & 43.38 & 22 & $\mathrm{E}$ & $\mathrm{Y}$ \\
\hline H419-10-6-2-1-17 & 43.24 & 18 & $\mathrm{E}$ & $\mathrm{Y}$ \\
\hline H419-10-6-2-1-6 & 42.94 & 4 & M & $\mathrm{R}$ \\
\hline H419-10-6-2-1-7 & 42.62 & 10 & $\mathrm{E}$ & $\mathrm{Y}$ \\
\hline H419-10-6-2-3-8 & 41.65 & 22 & $\mathrm{E}$ & $\mathrm{Y}$ \\
\hline H419-10-6-2-3-8 & 41.55 & 18 & $\mathrm{E}$ & $\mathrm{Y}$ \\
\hline H419-10-6-2-3-34 & 40.82 & 11 & $\mathrm{E}$ & $\mathrm{Y}$ \\
\hline UFV 8710 & 40.24 & 9 & M & $\mathrm{R}$ \\
\hline H419-10-5-1-4-8 & 39.58 & 17 & $\mathrm{E}$ & $\mathrm{R}$ \\
\hline H419-10-6-2-3-16 & 39.24 & 12 & $\mathrm{E}$ & $\mathrm{Y}$ \\
\hline H419-10-6-2-3-21 & 39.10 & 8 & $\mathrm{E}$ & $\mathrm{Y}$ \\
\hline H419-10-5-1-3-5 & 38.51 & 19 & $\mathrm{E}$ & $\mathrm{R}$ \\
\hline H514-7-10-6-14 & 38.16 & 7 & M & $\mathrm{R}$ \\
\hline H419-10-6-2-3-20 & 38.15 & 13 & $\mathrm{E}$ & $\mathrm{Y}$ \\
\hline CatuaíVermelho IAC 15 & 43.50 & 7 & $\mathrm{E}$ & $\mathrm{R}$ \\
\hline Obatã IAC 1669-20 & 41.40 & 13 & M & $\mathrm{R}$ \\
\hline CatucaíAmarelo 2SLCAK & 40.94 & 9 & $\mathrm{E}$ & Y \\
\hline Catuaí Vermelho & 37.55 & 12 & $\mathrm{E}$ & $\mathrm{R}$ \\
\hline Topázio MG 1190 & 37.10 & 16 & $\mathrm{E}$ & $\mathrm{Y}$ \\
\hline IcatuVermelho & 34.13 & 11 & M & $\mathrm{R}$ \\
\hline Oeiras MG 6851 & 33.28 & 13 & $\mathrm{E}$ & $\mathrm{R}$ \\
\hline Paraíso MG H419-1 & 33.08 & 17 & $\mathrm{E}$ & $\mathrm{Y}$ \\
\hline Bourbon Amarelo MG0007 & 26.03 & 12 & $\mathrm{E}$ & $\mathrm{Y}$ \\
\hline Bourbon da Terra & 24.86 & 15 & $\mathrm{E}$ & $\mathrm{Y}$ \\
\hline Bourbon Amarelo UFV 535 & 23.12 & 19 & $\mathrm{E}$ & $\mathrm{Y}$ \\
\hline Overall Mean & 32.55 & 15 & & \\
\hline Mean selected progenies (10) & 47.92 & & & \\
\hline Gain from Selection $(\%)$ & 44.04 & & & \\
\hline
\end{tabular}

${ }^{1} \mathrm{E}=$ Early; $\mathrm{M}=$ Medium; $\mathrm{L}=$ Late.

${ }^{2} \mathrm{R}=$ Red; $\mathrm{Y}=$ Yellow.

Ciência Rural, v.45, n.7, jul, 2015. 
selection of superior genotypes and indicate the proportion of genetic variance on total phenotypic variance, i.e., the inheritable proportion of total variability.

The yield of the genotypes was the main criterion used to measure their tolerance to heat stress. WAHID et al. (2007) state that tolerance to heat stress is the ability of the plant to develop and produce under high temperature conditions. The significant difference detected among the genotypes indicates the existence of genetic variability. Based on a selection intensity of $8 \%$, the 10 progenies that showed greatest green coffee production were selected. FALCONER \& MACKAY (1996) showed that the yield trait of grains is governed by various genes with small effect on the phenotype, classifying this as a quantitative trait; in other words, there is a strong effect of the environment on expression of this trait

The gain from selection obtained was of 14.33 bags ha ${ }^{-1}$, which is equivalent to an increase of $44.04 \%$ in green coffee production. The progeny H514-7-10-6-2-3-9 stood out, with mean yield of 51.20 bags ha $^{-1}$ (Table 2 ). The progenies H514-7-10-6-2-3-9, H514-7-10-6-9, H514-710-6-23 were the most stable, exhibiting a low occurrence of the biennial cycle (Figure 2).

As of evaluation of four crop seasons, it was possible to estimate the coefficient of repeatability for green cofee yield. With four harvests, a coefficient of determination of $87.91 \%$ was obtained, indicating that the evaluation over four crop seasons was sufficient for obtaining accurate estimates of the genetic parameters. In beginning phases of breeding programs, in which one wishes to eliminate those genotypes which are not promising, selection based on only two or three harvests is often used by breeders (OLIVEIRA et al., 2011). On the other hand, for Value for Cultivation and Use trials, at least four harvests in the greatest number of locations possible is necessary since we are dealing with the introduction of new cultivars.

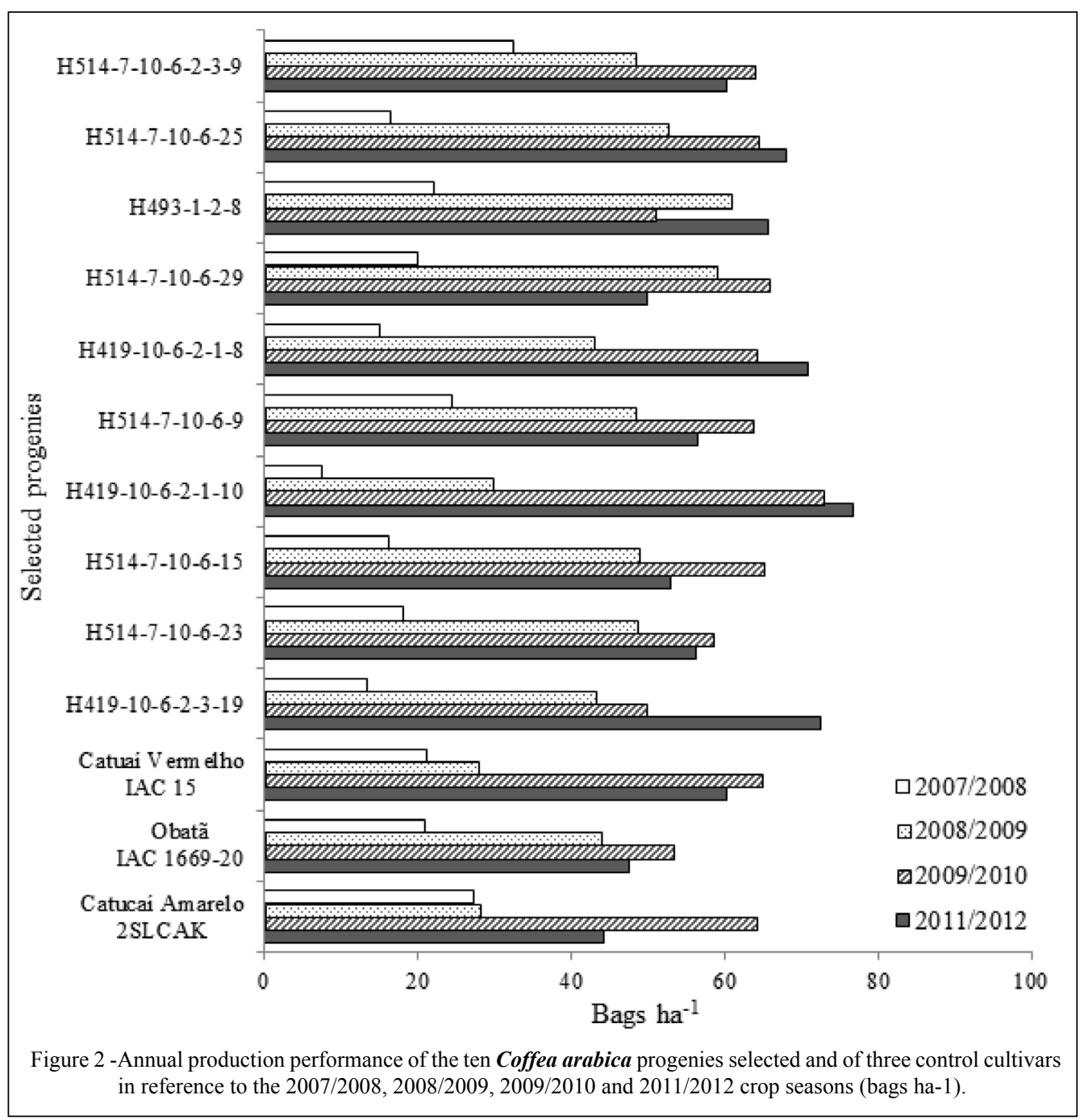

Ciência Rural, v.45, n.7, jul, 2015. 
In relation to the maturation cycle, it was observed that all the harvests were carried out in the months of February and March. In relation to the difference among progenies, $56 \%$ of them were classified as early cycle and $44 \%$ as medium cycle. Genotypes that exhibited a late cycle (harvest in April) were not observed.According to BARDINCAMPAROTTO et al. (2012), the heat factor has an effect on the maturation cycle of the coffee fruits, which when subjected to heat stress conditions tend to present an earlier maturation cycle. The maturation cycle was not used as a selective criterion; however, it was necessary to evaluate it since the goal is introducing both early and late cycle cultivars on the market.

Historically, January and February are the best months for negotiations in the coffee market. In this period, arabica coffee price quotes are, on average, $40 \%$ greater than the values registered throughout the year. On the other hand, these are the months in which the greatest volumes of rainfall in the state are concentrated, making the use of dryers or covered yards necessary for coffee drying.

\section{CONCLUSION}

Significant genetic variability was detected for green coffee production among arabica coffee progenies grown under high temperature conditions in the coffee growing regions of the state of Rondonia. Through the evaluations could be selected ten progenies that showed greatest green coffee production were selected, with mean yield greater than 45 bags ha ${ }^{-1}$.

\section{REFERENCES}

ABIC. Estatísticas. Produção Agrícola, 20 dez. 2012. Online. Available from: <http://www.abic.com.br/estatisticas.html $>$. Accessed: Jan. 15, 2013.

BARDIN-CAMPAROTTO, L. et al. Época provável de maturação para diferentes cultivares de café arábica para o Estado de São Paulo. Ciência Rural, v.42, n.4, p.594-599, 2012. Available from: $<$ http://www.scielo.br/scielo.php?script=sci arttext\&pid=S010384782012000400003\&nr=iso >. Accessed: Dec. 10, 2012. doi: 10.1590/S0103-84782012000400003.

BERGO, C.L. et al.Evaluation of Arabica and Robusta coffee genotypes in the state of Acre. Ciência e Agrotecnologia, v.32, n.1, p.11-16, 2008. Available from: <http://dx.doi.org/10.1590/ S1413-70542008000100001>. Accessed: Oct. 02, 2012. doi: 10.1590/S1413-70542008000100001.

BORÉM, A. Melhoramento de espécies cultivadas. Viçosa: UFV, 2005. 969p.
CAMARGO, A.P. Florescimento e frutificação de café arábica nas diferentes regiões cafeeiras do Brasil. Pesquisa Agropecuária Brasileira, v.20, p.831-839, 1985.

CAMARGO, M.B.P. The impact of climatic variability and climate change on arabic coffee crop in Brazil. Bragantia, v.69, n.1, p.239247, 2010. Available from: <http://dx.doi.org/10.1590/S000687052010000100030>. Accessed: Sept. 08, 2012. doi: 10.1590/ S0006-87052010000100030.

CRUZ, C.D. Programa Genes: biometria. Viçosa: UFV, 2006. 382p.

DAMATTA, F.M.; RAMALHO, J.D.C. Impacts of drought and temperature stress on coffee physiology and production: a review. Brazilian Journal of Plant Physiology, v.18, p.5581, 2006. Available from: <http://dx.doi.org/10.1590/S167704202006000100006>. Accessed: Ago. 18, 2011. doi: 10.1590/ S1677-04202006000100006.

FALCONER, D.S.; MACKAY, T.F.C. Introduction to quantitative genetics. Edinburgh: Longman Group Limited, 1996.463p.

FAZUOLI, L.C. et al. Aquecimento global, mudanças climáticas e a cafeicultura paulista. O Agronômico, v.59, n.1, p.19-20, 2007. Available from: $<$ http://www.iac.sp.gov.br/publicacoes/agronomico/ pdf/v59_paginasazuis_19e20.pdf $>$. Accessed: Ago. 12, 2012.

MEDINA FILHO, H.P.; BORDIGNON, R. Rendimento Intrínseco: um critério adicional para selecionar cafeeiros mais rentáveis. O Agronômico, v.55, n.2, p.24-26, 2003. Available from: $<$ http://www.iac.sp.gov.br/publicacoes/agronomico/pdf/v552_infotecrendimento.pdf $>$. Accessed: Nov. 07, 2012.

MOHSIN, T. et al. Heritability, phenotypic correlation and path coefficient studies for some agronomic characters in synthetic elite lines of wheat. Journal of Food, Agriculture \& Environment, v.7, n.3-4, p.278-282, 2009. Available from: <http://www.worldfood.net/scientficjournal/2009/issue3/pdf/agriculture/15.pdf $>$. Accessed: Oct. 30, 2012.

OLIVEIRA, A.C.B.D. et al. Prediction of genetic gains from selection in Arabica coffee progenies. Crop Breeding and Applied Biotechnology, v.11, n.2, p.106-113, 2011.

RESENDE, M.D.V.; DUARTE, J.B. Precisão e controle de qualidade em experimentos de avaliação de cultivares. Pesquisa Agropecuária Tropical, v.37, n.3, p.182-194, 2007. Available from: $<$ http://www.revistas.ufg.br/index.php/pat/article/view/1867>. Accessed: Jul. 06, 2012.

SOUZA, F.D.F.; SANTOS, M.M.D. Melhoramento genético do café canéfora em Rondônia. In: ZAMBOLIN, L.(Ed.).Tecnologias para produção do café Conilon. Viçosa: DFT/UFV, 2009. Cap.7, p.175-200.

SOUZA, M.A. et al. Melhoramento para tolerância ao calor.In: FRITSCHE, N.; BORÉM, A.(Ed.). Melhoramento de plantas para condições de estresses abióticos. Viçosa: Suprema, 2011. Cap.9, p.199-226.

WAHID, A. et al. Heat tolerance in plants: an overview. Environmental and Experimental Botany, v.61, n.3, p.199-223, 2007. Available from: <http://www.sciencedirect.com/science/ article/pii/S0098847207000871>. Accessed: Set. 30, 2012. doi: 10.1016/j.envexpbot.2007.05.011. 